\title{
The trip quality and value of non-Muslim tourists visiting Malaysia
}

\author{
Dr. Mohamed Battour
}

Faculty of Commerce, Tanta University

Faculty of business and accountancy, University of Malaya, Email: mohamedbator@gmail.com; mbattour@um.edu.my 


\title{
The trip quality and value of non-Muslim tourists visiting Malaysia ${ }^{1}$ \\ Dr. Mohamed Battour \\ Faculty of Commerce, Tanta University \\ Faculty of business and accountancy, University of Malaya, \\ Email: mohamedbator@gmail.com; mbattour@um.edu.my
}

\begin{abstract}
There is now a growing interest in halal products and services in tourism industry from the perspectives of both industry and academic research. This paper investigated the perception of non-Muslim tourists (predominately Western) towards Halal products and services in tourism industry in Malaysia. It also examined the actual extent to which non-Muslim tourists are willing to purchase certain types of halal products and services. Quantitative data was collected from 474 non-Muslim tourists visiting Malaysia. The results supported that the positive perception of halal tourism products/ services positively influence trip quality and value. The results identified the most important products and services in halal tourism that restrict trip quality and value for non-Muslim tourists. This paper is expected to provide some suggestions for destination marketers to be able to cater for the Western tourists and increase its trip quality and value.
\end{abstract}

Key words: Halal products, Halal service, Muslim friendly, destination marketing

\footnotetext{
${ }^{1}$ The authors would like to acknowledge University of Malaya for financial support. This work was supported by the High Impact Research Grant (UM.C/625/1/HIR/ASH/032).
} 


\section{The trip quality and value of non-Muslim tourists visiting Malaysia}

\section{Introduction}

The marketing of Halal products and services is not an easy task in tourism industry because of the variance between the demands of non-Muslim tourists and Muslim tourists. The modern image of destinations in countries where Islam is the core religion is still closely related with variances between traditional Islamic behavioural norms and those of Western civilization (Henderson, 2006; Tasci, Meydan, \& Cavusgil, 2006). Therefore, the development of Halal products and services in tourism industry and the need to attract international tourists has led to conflicts and is considered as a challenge for marketing Muslim destinations. Malaysia is considered a popular Islamic tourist destination in the world owing to its Islamic environment. Malaysia where Islam is the main religion take initiatives to develop Halal products and services in tourism industry because of the potential contribution to economic (H.-J. Chen, Chen, \& Okumus, 2013; Henderson, 2003; Loganathan \& Ibrahim, 2010). However, Halal products and services could be seen as constraints to tourism destination development. These constraints are critical and big challenge to tourism planning and marketing. Thus, Muslim tourism destinations should develop strategies to overwhelmed perceived constraints and increase trip quality and value.

A destination can increase the likelihood of its selection by marketing its ability to meet the requirements that their selected travel segments consider important. Halal products and services is not exclusive and promoted for Muslim market only(ElGohary, 2016). There are some spheres of Halal hospitality where non-Muslims can be observed as potential market segments (Stephenson 2014). The non-Muslim tourist may decide not to travel to a particular destination in the absence of certain attributes or applying specific restrictions (Battour, Ismail, \& Battor, 2011;2014). The challenge for Islamic destination is how to cater for non-Muslim tourist and satisfy their needs without clashing with Islamic teaching. This challenge is obvious, for example, in Shari'a compliant hotels where alcohol beverages are prohibited or Islamic resorts where beaches are separated by gender. Tourists from countries used to freedom of action in their holidays may not travel to a destination that practices halal tourism or they may respect and practice responsible tourism only if they share the similar beliefs as the local municipal (Jafari \& Scott, 2014). 
Religion is known to influence people's perception and behaviour (M. Battour, Ismail, Battor, \& Awais, 2014). Although Halal tourism has been covered recently in destination marketing literature (M. Battour \& Ismail, 2016; M. M. Battour, Ismail, \& Battor, 2010; Carboni, Perelli, \& Sistu, 2014; El-Gohary, 2016; Henderson, 2016; Ryan, 2016) but there remains a shortage publications to address the perception of non-Muslim tourist towards Halal products and services in tourism industry and the experience of visiting Muslim destination and its impact on trip quality and trip value. future research is recommended by Battour and Ismail (2016) to study non-Muslim perceptions related to Halal tourism practices. Comparative study is recommended to examine the relation between Halal and non-Halal tourists and to what degree they differ (Ryan, 2016). It is also recommended to study the interest of non-Muslims to halal food in Halal tourism market (Henderson, 2016). Stephenson (2014) also recommended study to identify the perceptions and experiences of non-Muslim tourists those are looking for health-conscious lifestyles and are socially minded and grateful of other cultures and societies. It is important to study how a non-Western view of leisure ritual rather than pilgrimage (Higgins-Desbiolles, 2006) and the universal worldview the Islam presents can deliver a useful model (Jafari and Scott 2014). Halal tourism practices may have a negative influence on the perception of non-Muslim tourists when they visited Muslim country(Zamani-Farahani \& Musa, 2012). Therefore, this study helps clarify aspects that have received limited attention in destination marketing literature. This paper assesses the answers to the encounters of effectively harmonising the demands of developing Halal tourism and needs of those are looking for modern international tourism.

Several authors have already pointed out the need for in-depth quantitative and qualitative studies on the coexistence between Muslim and non-Muslim tourists in the same destination (M. Battour \& Ismail, 2016; J. C. Henderson, 2010; ZamaniFarahani \& Henderson, 2010), or within different countries and countries with different tourism traditions (Zamani-Farahani \& Henderson, 2010; Zamani-Farahani \&Musa, 2012), or studies measuring different groups' perceptions on all these themes (Carboni et al., 2014). Despite the importance of these issues, limited studies have focused on Halal products and services in tourism and western tourists perceptions. Thus, the objective of this study is to measure the perception of non-Muslim tourists towards Halal products and services and its impact on trip quality and trip value in 
tourism industry in Malaysia. This paper is also expected to provide some suggestions for destination marketers to be able to cater for the Western tourists and increase its trip quality and trip value.

\section{Literature review}

\section{Halal and Muslim friendly products/ services in tourism}

Tourism recognizes the growing interest in halal tourism from both the perspectives of industry and research. Halal tourism terminology is appeared recently in destination marketing literature (Ryan, 2016), with Scopus revealing that one of the first papers in year 2010 (Battour, Ismail, \& Battour, 2010). Halal tourism can be summarized by any object or action which is permissible to use or engage in tourism industry, according to Islamic teachings (M. Battour \& Ismail, 2016). Halal tourism is also defined as a type of religious tourism that represents allowable activities under the Islamic teachings in terms of behaviour, dress, conduct and diet (Javed, 2007; WTM, 2007). Although various research have been conducted in destination marketing to develop successful Halal tourism model (M. Battour, Battor, \& Bhatti, 2013; M. Battour, Ismail, \& Battor, 2011; M. Battour et al., 2014; M. M. Battour et al., 2010; Eid \& El-Gohary, 2015; Jafari \& Scott, 2014). However, no research have done to explore the perception of non-Muslim tourists towards Halal tourism activities/rules and to what extend Halal tourism products/services could be consumed by non-Muslim tourists. Researches on halal tourism have mainly gone around a number of theoretical and practical issues including the availability of Islamic attributes to satisfy Muslim tourists on destination (M. Battour et al., 2013; M. Battour et al., 2011; M. Battour et al., 2014; M. M. Battour et al., 2010; Eid \& ElGohary, 2015; Henderson, 2003; Jafari \& Scott, 2014; Mohsin \& Ryan, 1997; Syed, 2001), the economic impacts of religious tourism (Raj \& Morpeth, 2007; Vukonic, 2002), motivation of religious tourists (Fleischer, 2000; Poria, Butler, \& Airey, 2003; Timothy, Timothy, \& Olsen, 2006).

Numbers of Shari'a compliant hotels is growing in Halal tourism market and could be found in some Muslim and non-Muslim destinations (M. Battour \& Ismail, 2016; Carboni \& Janati, 2016). Some of these destinations promote Shari'a compliant hotels as 'Muslim-friendly hotels'(Carboni et al., 2014). Some authors have discussed how hotels can be developed to be Shari'a compliant (M. M. Battour et al., 2010; Joan C Henderson, 2010; Ozdemir \& Met, 2012; Zulkharnain \& Jamal, 2012). For example, 
Muslim friendly hotels deliver Muslim guests with all services that compliant with Islamic teachings such as Qibla Direction, prayer mat, Halal food, alcohol-free beverages, and prayer room with call for prayers (M. M. Battour et al., 2010; Joan C Henderson, 2010; Javed, 2007; Stephenson, 2014). Segregated accommodation is applied in terms of 'Women only-floor' and 'family only-floor' for the purpose of security and privacy. This concept is also offered in some western hotels such as the Georgian Court Hotel in Vancouver (Stephenson, 2014). Segregation concept is also applied in beaches and swimming pool (M. Battour \& Ismail, 2016). Batrawy (2015) gives examples of a rental company in Orlando, Florida, that provides 'halal vacation homes'; Separated pools, rooms with prayer mats and copies of the Quran.

Availability of Halal food and beverages is common in Muslim destination and Muslim tourists request Halal food and beverages when they visit non-Muslim destinations (Euromonitor International, 2015, p. 17). According to Sharia'h law, it is not allowed for Muslim followers to eat pork, animals that were dead former to slaughtering, animals not slaughtered with saying the name of Allah, blood, alcohol, predatory animals, birds of prey (M. Battour et al., 2014; M. M. Battour et al., 2010; Dugan, 1994; Stephenson, 2014). Furthermore, drinking or selling alcohol is also prohibited for Muslims. Moreover, visiting places where alcohol beverages is sold and gambling is practised is not allowed (M. Battour et al., 2011; Din, 1989; Hashim, Murphy, \& Hashim, 2007). Halal food products may appeal to non-Muslims demand because of safety and hygiene matters. For example, Marhaba, a Dutch company attract a quarter of its tourists from the non-Muslim segment by selling them halal biscuits and chocolates (Stephenson, 2014). Furthermore, Middle Eastern full-service and fast food restaurants which serve Halal food for Muslim tourists are very prevalent in France, Germany and the UK and some of their tourists may be frequently non-Muslim (Euromonitor International, 2015, p. 16).

According to Islamic ethics, prostitution and adultery is prohibited for Muslims. Activities deemed encouraging to sexual permissiveness are not permitted in public (Din, 1989; Henderson, 2008; Zamani-Farahani \& Henderson, 2010). These rules may disturb non-Muslim tourists if obligated to be followed when they visit Muslim country. Instead of bikinis, Burqini or burkini swimsuit is a type of swimsuit for women intended to comply with Islamic ethics for Muslim women to dress modestly 
(Euromonitor International, 2015, p. 24). Wearing Burqini are likely to be increased by Muslim and non-Muslim women as they identify its several benefits, including sun protection, flexibility and modesty. Furthermore, non-Muslim tourists may be requested to wear Islamic attire when visiting holy places such Masjids (Henderson, 2003). However, some resorts in Morocco ban it in their pools which is against Muslim-friendly services such as women-only pools, different time sessions for the exclusive use of the swimming pool of either men or women (Al Arabiya News, 2014; Henderson, 2006).

Muslim friendly products and services are growing in tourism market., For example, 'halal spas' and halal-friendly cosmetics are increasingly popular in Indonesia (Stephenson, 2014).

\section{Visitor perception}

One of the cultural forces that have influence on perception and behaviour is religion (Delener, 1994; Essoo \& Dibb, 2004; Zamani-Farahani \& Musa, 2012). Therefore, Religion affects the perception of people towards others. According to the Social Distance Theory, Thyne et al. (2006) indicated that people are more easy-going to others who are sharing the same social and cultural environment. Moreover, Religion as long as the tourism industry operation, tourism policy-making and destination development impacts individual host and guest experiences (Zamani-Farahani \& Henderson, 2010; Zamani-Farahani \& Musa, 2012). Andriotis (2005) suggests measuring residents' perceptions and the perception of other community groups or tourism shareholders as their views are also energetic in ensuring the future success of tourism development. It is noticed recently that there is religion conflict, with a focus on how believers to different religions often clash in tourist destinations (CohenHattab, 2010; Nyaupane, Timothy, \& Poudel, 2015). Therefore, misunderstanding could be found between believers and non-believers when tourists from different faiths interconnect with residents at destinations visited (Henderson, 2003). This is particularly deceptive in the case of non-Muslim tourists visiting Muslim country.

Travellers those are believers and non-believers at all, are motivated by several intentions, and sometimes their purposes are not in harmony with those of other travellers (Nyaupane et al., 2015). Although the relationship between Islam and secular in tourism development is addressed in literature (M. Battour \& Ismail, 2016; Eid \& El-Gohary, 2015) but the relationship between Halal tourism and secular 
tourism model is still not well explained. There is no doubt that Halal tourism is a good business opportunity that could satisfy Muslim and non-Muslim tourists over time and time (M. M. Battour et al., 2010). However, the ignorance of the needs of non-Muslim travellers in the area of destination marketing could lead to lose considerable profit from the international tourism market. The Conflict practices between western demands and Halal tourism making cater for both Muslim and nonMuslim tourists are a big challenge for destination markers (M. Battour \& Ismail, 2014) . It seems that Halal tourism could contribute to economy growth but at the same time it could be a thoughtful barrier to tourism development, and could lead to the absence of large numbers of Western tourists (Zamani-Farahani \& Henderson, 2010). Moreover, Fari and Scott (2014) raised an important question related to the possibility of Halal tourism operations to cater for Western tourists and how it would increase or decrease its international arrivals.

A happy host is vital to create a positive destination image which then creates positive word of mouth (Snaith \& Haley, 1999) . Stiff competition among destination marketers, as well as the saturated marketplace, requires proper understanding of the factors that influence visitor perception (M. Battour et al., 2011). Destination marketers must understand whether Halal tourism practices may affect tourists to keep coming to visit certain destinations (M. Battour \& Ismail, 2016). It is also important to examine whether Halal tourism practices applies to all segments or only to selected segments. For example, Battour et al. (2010) claim that Halal tourism could be one of the motivation for non-Muslim tourists who are looking for a cultural experience. However, Some Muslim countries don not encourage inbound tourism from nonMuslim tourists (Robinson \& Meaton, 2005) because of immoral effects of tourism and its impacts on the local community (Din, 1989). Negative perception is also found regarding the behaviour of inbound tourists as they are extreme tourists of sex, alcohol, food and natural resources, and these can appeal negative attitudes among citizens towards tourists (Aziz, 1995; Gössling, 2002; Mansperger, 1995; Teye, Sirakaya, \& Sönmez, 2002; Zamani-Farahani \& Musa, 2012). According to social, political, and religious differences, some middle-Eastern countries have avoided Western-style international tourism, believed the differences to be incompatible with Sharia (Burton, 1995). Brunei is an example of this strategy as a 'reluctant tourist 
destination' with no real economic inducement to encourage international tourism, thereby protects residents from the 'worst excesses' (H.-J. Chen et al., 2013).

Islamophobia is representing a challenge to multicultural exchanges and experiences. Consuming halal products and services by non-Muslims tourists in tourism industry could positively impact non-Muslims tourists minds (Western) to reduce Islamophobia. One of the best case of that is Malaysia as it is seen a modest Islamic country (Henderson, 2003), and this could be extend to another Islamic country such as Indonesia, Tunisia, and Turkey (Henderson, 2008). Therefore, a moderate country is a secular country that separate sharia from public life (Jafari and Scott 2014). In a modest Islamic country, a degree of liberalism is given to non-Muslims tourists to make their visit easier, while there are some obligations as hosts are normally appreciated by many Western tourists (Zamani-Farahani \& Henderson, 2010).

\section{Trip quality and trip value}

According to Binge et al.(2001), there are two type of quality: real quality and perceived quality. Real quality is the superiority of a product or service that is presented to consumers, but perceived quality is consumers' overall judgment about the excellence and supremacy of a product or service. Bingé et al. (2001) and Žabkar et al. (2010) (2010)stated that evaluation of quality is predominantly a cognitive process. Consumers' perceptions about the quality emerge from the difference between the performance and the expectations (Bingé et al., 2001). When the performance exceeds the expectations, quality increases. When the performance falls short of the expectations, quality decreases (Bingé et al., 2001). Thus, trip quality can be defined as 'travelers' perception of a destination's ability to fulfill their expectations" (Ferns \& Walls, 2012). It refers to tourists' feelings and overall evaluation of experiences in a destination(Cong, 2016).

Although it seems that quality and satisfaction are similar concepts, but they are different. With regard to quality, the expectations have been viewed as wishes or ideal results, whereas the expectations relating to satisfaction have been interpreted as predictions. Furthermore, the expectations of quality are based on perceptions of excellence or superiority, whereas those of satisfaction refer to need or equity. Another difference is that perceptions of quality are cognitive and more specific, 
while perceptions of satisfaction are affective and more holistic. Quality is dependent on price but satisfaction is not. Finally, satisfaction is a post-consumption concept, whereas perceptions of quality can be made before consumption (Bingé et al., 2001). Trip quality is recognized as a key factor to achieve the success of tourist destinations. There is no doubt that experience quality is an effective factor in travel decisionmaking behavior and the destination choice of tourists. When people want to take a travel to a particular destination, they remember their past experiences at the first stage, and then they decide to go to the destination or select another destination. Indeed, past experiences are recorded in the minds of tourists and affect the future travel behavior (Kim, Ritchie, \& McCormick, 2010). Trip quality determines the number of tourists in a destination and thereby profit, reputation, and the success of the destination(Jennings \& Weiler, 2006), so the experience offered by a destination must be memorable to gain competitive advantage when compared to other destinations (Chen \& Tsai, 2007; Žabkar et al., 2010). In the destination literature, trip quality has empirically been found to have the significant effect on trip value (C.-F. Chen \& Tsai, 2007), tourist satisfaction and loyalty (Bingé et al., 2001).

Value can be viewed by the following things: (1) low price, (2) whatever a consumer wants from a product, (3) the quality that a consumer gets for the price paid, and (4) what a consumer gets against what he/she gives (Bajs, 2015). Perceived value is regarded as the evaluation of a consumer about his/her consumption on the basis of his/her comparison between the advantages obtained from a product or service and the perceived sacrifices (Akhoondnejad, 2015; C.-F. Chen \& Tsai, 2007; Forgas-Coll, Palau-Saumell, Sánchez-García, \& Callarisa-Fiol, 2012; Song, Su, \& Li, 2013). The advantages include the quality of the product or service and psychological advantages, whereas the sacrifices include the money, time, effort, risk, and convenience (ForgasColl et al., 2012; Gallarza \& Gil Saura, 2006; Pandža Bajs, 2015). This conceptualization of value as a trade-off between get and give elements has resulted in a universal interest on the composite nature of value(Gallarza \& Saura, 2006).

In the context of tourist destination, a tourist would evaluate the value of a destination based on the difference between the advantages offered by the destination and the sacrifices. In other words, perceived value of a destination can be viewed as a trade-off between the travel time, money, and effort on the one hand and experience 
gained from the visitation on the other hand (Pandža Bajs, 2015). Thus, a destination value increases when a tourist perceives that the destination offers much benefits than what the tourists spends in terms of money, time, and effort. Providing superior value to consumers is necessary to survive and succeed. Value is also recognized as a good way to differentiate products or services and gain competitive advantage, because it is acknowledged as a good driving force of consumption decisions (Gallarza \& Gil Saura, 2006). Indeed, value is a major factor influencing consumer decision-making behaviour both at the pre-consumption and post-consumption stages(Gursoy, S. Chen, \& G. Chi, 2014). Likewise, tourist destinations' competitiveness is heavily dependent on their ability to deliver superior experiences to tourists (Gallarza \& Gil Saura, 2006; Song et al., 2013). Perceived value of a destination has a significant effect on the destination choice of tourists (Pandža Bajs, 2015). In the destination literature, trip value has empirically been demonstrated as a significant predictor of tourist satisfaction (Chen \& Tsai, 2007; Forgas-Coll et al., 2012; Gallarza \& Gil

Saura, 2006; Pandža Bajs, 2015; Song et al., 2013) and loyalty (Pandža Bajs, 2015; Song et al., 2013). Likewise, in Iran, it was found a positive relationship between fisttime visitors' perceptions of trip value and their satisfaction as well as revisit and recommend intentions in a recent research by Akhoondnejad (2015).

As such, this research proposes the following hypotheses:

H1: The perception of Halal tourism products /services (PHTPS) positively influence trip quality

H2: The perception of Halal tourism products /services (PHTPS) positively influence trip value.

H3: Trip quality positively influence trip value.

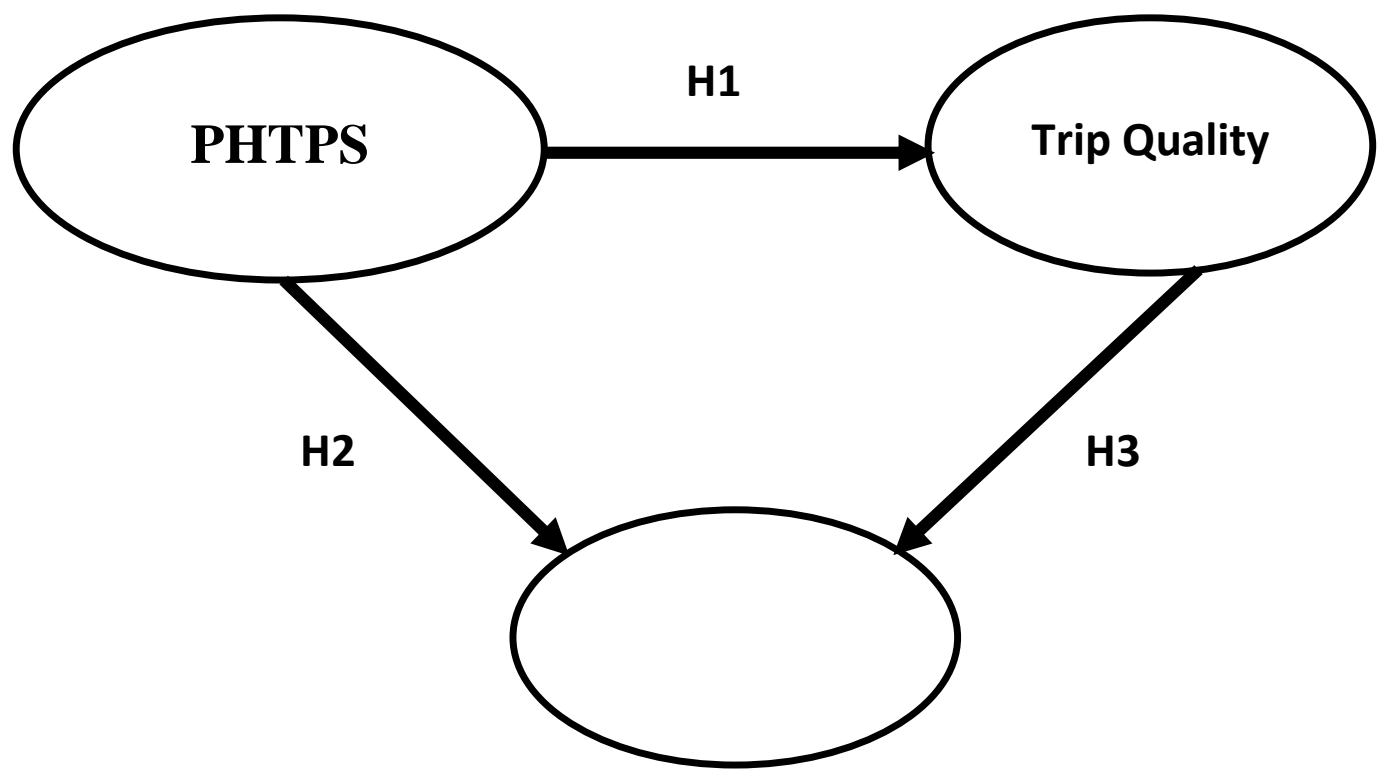

Figure 1: Theoretical framework

Note: Perception of Halal tourism products/ services, (PHTPS) 


\section{Research Method \\ Questionnaire design}

The objective of this study is to measure the perception of non-Muslim tourists towards Halal products and services and its impact on trip quality and trip value in tourism industry in Malaysia. In order to achieve this objective, self-administered questionnaire was developed to capture perception of Halal Tourism products/ services, Trip quality, and trip value. a list of measurement items was extracted after conducting qualitative research and extensively analyzing literature review. The questionnaire is in four sections. First section, all items were measured by a 5-point Likert scale $(1=$ extremely disagree to $5=$ extremely agree $)$. A multi-attribute scale was used to measure the experience of Halal products and services in tourism sector such as Muslim-friendly hotels, Halal food, segregation in swimming pool and beaches, prayer facilities, Islamic ethics, and Islamic dress code. Second section, Base on Kim et al. (2012), seven items were employed to measure trip quality: different experience, friendly local people, refreshing experience, meaningful experience, wanted place, and exploratory experience. Third section, three items were used from Chen \& Tsai (2007) to measure trip value as follows: value for money, value for effort, and value for time. Section four, questions about respondents' sociodemographic attributes.

This study was conducted by distributing 1100 questionnaires from January to February 2016 in international hotels and tourism sites in the capital city of Malaysia (Kuala Lumpur). The questionnaires were given to non-Muslim tourists following a convenience sampling approach. The demographic profile of the sample indicated that gender distribution of the participants was $59.8 \%$ female and $40.2 \%$ male. Nationalities of the participants were as follows: Denmark, Japan, England, America, Poland, Iceland, Sweden, Spain, France, Germany, Australia, Italy, Portugal, Netherlands, Russia, India, Canada, Armenia, Ireland, and Switzerland. 23.6\% of the participants were aged 36-45 years old, followed by 26-35 years old (20.5\%), 46-55 years old (18.2\%), 56-65 years old (18.2\%), over 65 years old (14.0\%), and 15-25 years old (5.5\%). $61.0 \%$ of the sample had a university degree and over, $28.3 \%$ high school, 9.6\% middle school, and $1.0 \%$ primary school. $36.4 \%$ of the participants had an annually household income between 30001-40000, 23.6\% of them earned 20000$30000,20.0 \%$ of them earned $40001-50000,12.7 \%$ of them earned more than 50000 , 
and $7.3 \%$ them earned less than $\$ 20000$. In terms of religion, $75.4 \%$ of the participants were Christian, $24.6 \%$ had other or no religion. In terms of religiosity, $12.1 \%$ categorized themselves as secular, $16.8 \%$ as mildly religious, $48.4 \%$ as religious, and $22.7 \%$ as very religious.

\section{Measurement and structure model}

EFA and CFA were performed for the purpose of data reduction in perception of Halal tourism products and services (PHTPS). The principal components analysis method was selected to apply EFA and CFA. The items with a factor loading above the cut-off point $|0.50|$ are retained for further analysis (Hair, 2010). All of these procedures were performed using SPSS 19. To achieve a good reliability, Cronbach's alpha should be 0.7 or higher (Hair et al., 2010, p. 125). To establish the convergent validity, the average variance extracted (AVE) should be more than 0.50, (Fornell \& Larcker, 1981). To establish the discriminant validity, AVE should be larger than its shared variance with any other construct (Fornell \& Larcker, 1981). To investigate the relationship between variables and to test the hypotheses, the path analysis were applied using Structure equation model (SEM) /AMOS 19 software. The path coefficients and the R-squared values were used as basis for testing the hypotheses to determine whether they were statistically significant or not. The path coefficients determine the power of the relationship between variables. The R-squared value indicates the predictive power of a model for the endogenous variables. The significance of the paths is determined by computing the t-value.

\section{Data analysis and results}

\section{Dimensionality of Halal tourism perception}

Out of the 1100 questionnaires, 630 were completed and returned. This represented an effective response rate of $57.2 \%$. After data cleaning, the final sample size was 474 . With regard to the perception of Halal tourism products/ services, due to the fact that the measurement scale was a new scale, exploratory factor analysis (EFA) using principal component method with varimax rotation was performed to reduce the items used in the scale and identify the underlying factors. As shown in Table 1, the Bartlett test of sphericity was significant as the p-value was less than 0.05. Furthermore, KMO index exceeded the recommended value of 0.6. Thus, the data was suitable for factor analysis. Items with an eigenvalue of 1.0 or more and a factor loading of 0.5 or more 
were retained for including in a factor (Hair, 2010). All items had a factor loading more than 0.5 and an eigenvalue greater than 1.0. Therefore, all items were kept. Five factors were derived from the 29 items, which explained $59.9 \%$ of the variance of the perception of Halal tourism products and services. The first factor which was labeled "halal tourism general perception" consists of the eleven items. The second factor which was labeled "Halal Food" consists of seven items. The third factor which was labelled "gender segregation" consists of three items. The fourth factor was labelled "Islamic dress code" consists of four items. The fifth factor was labelled "Islamic ethics" consists of four items. Table 1 show that the EFA results indicate a high level of reliability, as all the alpha values are above the recommended threshold of 0.7.

Table 1: Exploratory factor analysis for PHTPS.

\begin{tabular}{|c|c|c|c|c|}
\hline Dimenstion \&items & $\begin{array}{l}\text { Factor } \\
\text { loading }\end{array}$ & $\begin{array}{r}\text { Variance } \\
\text { explained }\end{array}$ & Cronbach $\alpha$ & $\begin{array}{c}\text { Mean } \\
\text { (Std. D.v) }\end{array}$ \\
\hline Factor 1: general practise & & 18.39 & 0.882 & $3.6(.729)$ \\
\hline $\begin{array}{l}\text { I accept to visit Muslim countries which } \\
\text { apply certain sharia rules (Islamic teaching) }\end{array}$ & 0.67 & & & \\
\hline $\begin{array}{l}\text { It is a good chance to experience another } \\
\text { religion }\end{array}$ & 0.60 & & & \\
\hline $\begin{array}{l}\text { Visiting Muslim country as a somewhat of a } \\
\text { cultural shock }\end{array}$ & 0.64 & & & \\
\hline $\begin{array}{l}\text { It should be no obligation for non-Muslim } \\
\text { tourists to adhere with certain rules }\end{array}$ & 0.74 & & & \\
\hline $\begin{array}{l}\text { I know what is Halal tourism, Islamic } \\
\text { tourism, and Muslim friendly tourism }\end{array}$ & 0.58 & & & \\
\hline $\begin{array}{l}\text { I accept to wear Burqini /burkini swimsuit in } \\
\text { beaches or swimming pool. }\end{array}$ & 0.74 & & & \\
\hline $\begin{array}{l}\text { Wearing Burqini /burkini swimsuit is } \\
\text { considered new experience for me }\end{array}$ & 0.72 & & & \\
\hline $\begin{array}{l}\text { I accept to find some Muslim prayer } \\
\text { facilities in hotel rooms such Qibla direction, } \\
\text { copies of the Quran, or prayer mats }\end{array}$ & 0.69 & & & \\
\hline Holy books should be placed in hotel rooms & 0.62 & & & \\
\hline $\begin{array}{l}\text { Early morning call for prayer or Azan disturb } \\
\text { me }\end{array}$ & 0.52 & & & \\
\hline $\begin{array}{l}\text { Availability of water supply in toilets at } \\
\text { tourism sites, airport, shopping mall, hotel, } \\
\text { parks, etc. bother me }\end{array}$ & 0.67 & & & \\
\hline Factor 2: Halal Food & & 13.72 & 0.811 & $3.6(.529)$ \\
\hline $\begin{array}{l}\text { I accept to purchase halal products and } \\
\text { services (i.e hotel rooms in Muslim-friendly } \\
\text { hotels) }\end{array}$ & 0.69 & & & \\
\hline I accept to eat Halal meat & 0.63 & & & \\
\hline $\begin{array}{l}\text { I can replace pork with any other kind of } \\
\text { meat or fish }\end{array}$ & 0.73 & & & \\
\hline $\begin{array}{l}\text { I do not need to order alcoholic beverages in } \\
\text { hotels and restaurants. }\end{array}$ & 0.70 & & & \\
\hline $\begin{array}{l}\text { Banning of alcoholic drinks by the authority } \\
\text { at public places bother me }\end{array}$ & 0.60 & & & \\
\hline I can consume Halal food & 0.62 & & & \\
\hline Consuming Halal food is considered as a & 0.70 & & & \\
\hline
\end{tabular}




\begin{tabular}{|c|c|c|c|c|}
\hline new experience & & & & \\
\hline Factor 3: Islamic ethics & & 12.24 & .907 & $3.7(.525)$ \\
\hline Banning of prostitution activities bother me & 0.78 & & & \\
\hline $\begin{array}{l}\text { Banning by the authority of indecent display } \\
\text { of affection between sexes at public places } \\
\text { (such as kissing etc.) bother me }\end{array}$ & 0.76 & & & \\
\hline $\begin{array}{l}\text { Banning gambling and casino by the } \\
\text { authority bother me }\end{array}$ & 0.82 & & & \\
\hline $\begin{array}{l}\text { Censorship by the authority of adult scenes } \\
\text { in movies shown on TV bother me }\end{array}$ & 0.79 & & & \\
\hline Factor 4: gender segregation & & 8.68 & 0.772 & $3.2(.637)$ \\
\hline $\begin{array}{l}\text { I accept gender segregation at beaches, } \\
\text { swimming pools }\end{array}$ & 0.78 & & & \\
\hline $\begin{array}{l}\text { I accept to book a room at a hotel practice } \\
\text { gender segregation. }\end{array}$ & 0.80 & & & \\
\hline $\begin{array}{l}\text { I accept separate floor for single women at } \\
\text { hotel }\end{array}$ & 0.77 & & & \\
\hline Factor 5: Islamic dress code & & 6.80 & 0.755 & $3.4(.760)$ \\
\hline $\begin{array}{l}\text { Observation of Islamic dress code by hotel } \\
\text { and restaurant staff do not disturb me }\end{array}$ & 0.56 & & & \\
\hline $\begin{array}{l}\text { Prevalence of Islamic dress code (e.g. Hijab) } \\
\text { at public places do not disturb me }\end{array}$ & 0.52 & & & \\
\hline $\begin{array}{l}\text { I accept to wear Islamic dress if that is } \\
\text { required when visiting Islamic heritage sites } \\
\text { such as mosques or masjids. }\end{array}$ & 0.76 & & & \\
\hline $\begin{array}{l}\text { Taking off shoes before entering a mosque } \\
\text { does not bother me }\end{array}$ & 0.56 & & & \\
\hline Total variance explained & $59.84 \%$ & & & \\
\hline
\end{tabular}

After EFA, CFA was applied using AMOS 19 software as shown in Figure 2. Two items from the general perception, two items from Halal Food, one item from gender segregation and one item from Islamic ethics were dropped, as they could not survive the model diagnostic procedure. The results of the CFA of the modified models of the Perception of halal tourism products/ services are summarized in Table 2.

Table 2: CFA Fit Measures of the PHTPS Scale

\begin{tabular}{lcc}
\hline \multicolumn{1}{c}{ Fit Indices } & Estimates & $\begin{array}{c}\text { Acceptable } \\
\text { level }\end{array}$ \\
\hline Chi-square & 354.086 & \\
Degree of freedom (df) & 220 & \\
$P$ & .000 & $>0.05$ \\
Normed Chi-square (CMIN/DF) & 1.609 & $<3.00$ \\
Goodness-of-fit Index (GFI) & .941 & $\geq 0.90$ \\
Adjusted Goodness-of-fit Index (AGFI) & .926 & $\geq 0.90$ \\
Tucker-Lewis Index (TLI) & .962 & $\geq 0.90$ \\
Comparative Fit Index (CFI) & .967 & $\geq 0.90$ \\
Root Mean Square of Error of Estimation & & $\leq 0.08$ \\
(RMSEA) & .036 & \\
\hline
\end{tabular}




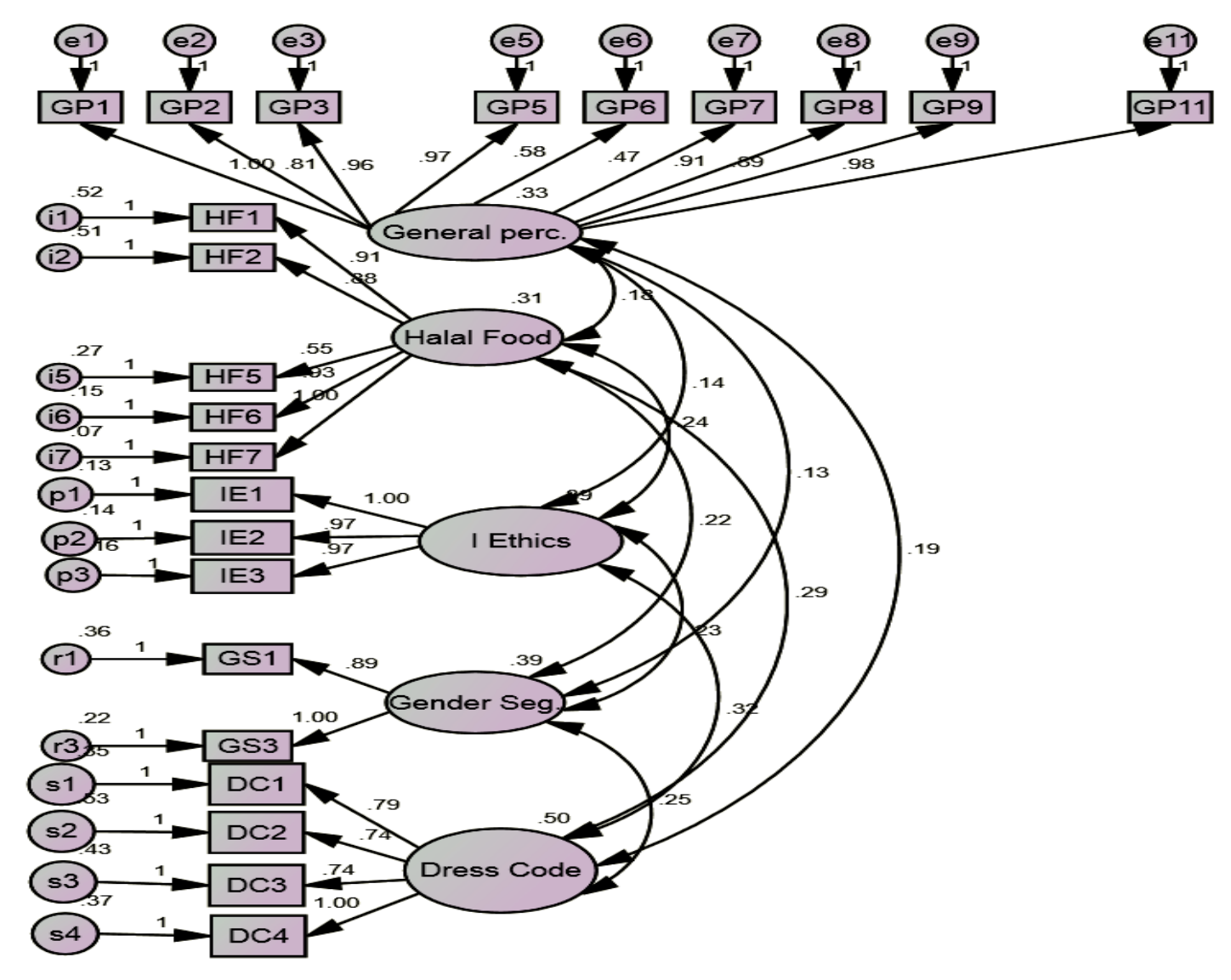

Figure 2: CFA of the PHTPS Scale

To measure the convergent validity, the results revealed that the AVE measures exceeded the recommended level of 0.50 for general practise of halal tourism (0.77), halal food (0.75), Islamic ethics (0.94), gender segregation (0.89), Islamic dress code (0.67), trip quality (0.83), and trip value (0.86). Table 3 shows the square root of the AVE (the bold number in the diagonal of the table), is more than the correlation values providing acceptable discriminant validity.

Table 3: Discriminant validity of measurement scales.

\begin{tabular}{|l|l|l|l|l|l|l|l|}
\hline & HTGP & HF & IE & GS & IDC & TQ & TV \\
\hline HTGP & $\mathbf{0 . 7 7}$ & & & & & & \\
\hline HF & $.497^{* *}$ & $\mathbf{0 . 7 5}$ & & & & & \\
\hline IE & $.340^{* *}$ & $.573^{* *}$ & $\mathbf{0 . 9 4}$ & & & & \\
\hline GS & $.301^{* *}$ & $.480^{* *}$ & $.490^{* *}$ & $\mathbf{0 . 8 9}$ & & & \\
\hline IDC & $.364^{* *}$ & $.563^{* *}$ & $.612^{* *}$ & $.421^{* *}$ & $\mathbf{0 . 6 7}$ & & \\
\hline TQ & $.405^{* *}$ & $.594^{* *}$ & $.475^{* *}$ & $.451^{* *}$ & $.501^{* *}$ & $\mathbf{0 . 8 3}$ & \\
\hline TV & $.217^{* *}$ & $.272^{* *}$ & $.101^{*}$ & $.189^{* *}$ & .078 & $.340^{* *}$ & $\mathbf{0 . 9 5}$ \\
\hline
\end{tabular}


Note: Key, HTGP, Halal tourism general perception; HF, Halal food; IE, Islamic

Ethics; GS, Gender segregation; IDC , Islamic dress code; TQ, Trip quality; TV, Trip Value.

\section{Hypotheses testing}

In order to test the hypothesized relationships, structural equation modeling (SEM) using maximum likelihood method was utilized. As shown in table 4, the goodnessof-fit indices of structural model were found to be acceptable. The results in table 5 indicated that perception of halal tourism products and services (PHTPS) positively influenced trip quality $(\mathrm{TQ})(\mathrm{B} 1=0.511, \mathrm{t}$-value $=11.04, \mathrm{p}<0.05)$ and trip value $(\mathrm{B} 2=0.146, \mathrm{t}$-value $=3.029, \mathrm{p}<0.05)$. Thus, $\mathrm{H} 1$ and H2 were supported. Trip quality was found to have the significantly positive effect on trip value $(\mathrm{B} 3=0.315$, $\mathrm{t}$-value $=$ 5.25, $\mathrm{p}<0.05)$. Thus, H3 was supported.

Table 4: structure model goodness of fit

\begin{tabular}{lcc}
\hline \multicolumn{1}{c}{ Fit Indices } & Estimates & $\begin{array}{c}\text { Acceptable } \\
\text { level }\end{array}$ \\
\hline Chi-square & 1400 & \\
Degree of freedom (df) & 487 & $>0.05$ \\
$P$ & .000 & $<3.00$ \\
Normed Chi-square (CMIN/DF) & 2.87 & $\geq 0.90$ \\
Goodness-of-fit Index (GFI) & .931 & $\geq 0.90$ \\
Adjusted Goodness-of-fit Index (AGFI) & .912 & $\geq 0.90$ \\
Tucker-Lewis Index (TLI) & .971 & $\geq 0.90$ \\
Comparative Fit Index (CFI) & .981 & $\leq 0.08$ \\
Root Mean Square of Error of Estimation & & .063 \\
(RMSEA) & .063 & \\
\hline
\end{tabular}

Table 5: Summary of hypotheses testing

\begin{tabular}{|l|c|c|c|c|}
\hline \multicolumn{1}{|c|}{ Hypotheses } & Path & $\begin{array}{c}\text { Path } \\
\text { coefficient }\end{array}$ & t-value & $\begin{array}{c}\text { ACCEPT } \\
\text { OR REJECT }\end{array}$ \\
\hline $\begin{array}{l}\text { H1:The perception of } \\
\text { Halal tourism products } \\
\text { /services positively } \\
\text { influence trip quality }\end{array}$ & PHTPS $\rightarrow$ TQ & 0.51 & $11.04^{*}$ & Accept \\
\hline $\begin{array}{l}\text { H2: The perception of } \\
\text { Halal tourism products } \\
\text { /services positively } \\
\text { influence trip value. }\end{array}$ & PHTPS $\rightarrow$ TV & 0.146 & $3.029^{*}$ & Accept \\
\hline $\begin{array}{l}\text { H3: Trip quality } \\
\text { positively influence trip } \\
\text { value. }\end{array}$ & TQ $\rightarrow \mathrm{TV}$ & 0.315 & $5.25^{*}$ & Accept \\
\hline
\end{tabular}




\section{Conclusions and Implications}

This study presents the findings of research designed to measure the impact of the perception of non-Muslim tourists towards Halal products and services visiting Malaysia in tourism industry, and its impact on trip value and trip quality. The final Structural Model results provided evidence that the relationship between the perception of halal tourism products and services, trip quality and trip value was statistically supported. The impact of PHTPS on trip quality is positive with explained variance 0.51 which is considered moderate. However, the impact of PHTPS on trip value is positive with explained variance 0.14 which is considered very low. The perceptions of non-Muslim tourists towards Halal products and services were moderately positive. The majority of them consider is a good opportunity to learn and to try Muslim culture. They are also willing to adhere to Muslim rules. However, the perception of some participants was considered negative because they considered Halal-tourism rules restrict their freedom to enjoy the visit. For example, 'wearing Burqini /burkini swimsuit in beaches or swimming pool' and 'replace pork with any other kind of meat or fish' and 'no need to order alcoholic beverages in hotels and restaurants' were found to be halal products and services that restrict non-Muslim tourists freedom and may decrease trip quality and value with a mean of 1.02, 1.04, 1.06 respectively. Majority of non-Muslim tourists (312 out of 474) don't accept to book a room at a hotel practice gender segregation with mean score 1.89 .

To overcome this conflict, tourism products and services providers should find innovative solutions that satisfy non-Muslim tourist and increase trip quality and value. Furthermore, tourism operator should educate non-Muslim tourists about what halal tourism rules are. The findings also revealed that the majority of participants consider Muslim friendly hotels as an option if the price is reasonable. This finding provides an opportunity for this type of hotels to reach out to this specific category of tourists, i.e. those who seek to experience Muslim culture and experience. For wearing Burqini or burkini swimsuits, the results show that rule is very difficult to be applied to non-Muslims and could also be a travel constraint. Moreover, the findings reveal that Muslim prayer facilities in hotel room are accepted by majority of participants. However, the customization should be applied for all guests. Tourism marketers should utilize the emerging technologies. For example, innovative products 
should be created and applied to all tourists so the discrimination would not be noticed in hotel room. For example, the call for prayer early morning should be avoided for non-Muslim guests. The results supported that non-Muslim could try halal tourism experience, or at least purchase certain types of halal products and services. Therefore, this study suggests that countries with strong Islamic norms and values can be successfully promoted as travel destinations to non-Muslim tourists who are attracted to Islamic culture and halal hospitality.

Although the majority of participants are not happy with the banning of alcoholic beverages, innovative solution should be applied to solve this situation such as providing similar beverages without alcohol or replacing them with non-alcoholic juice and tea. The more innovative the alternatives that comply with sharia, the more support for trip quality and trip value in Halal tourism market. Moreover, positive perception is revealed regarding separate floors for single females and for families, especially if the female tourists are travelling alone or for those seeking for privacy and could not tolerate noises made by children. Furthermore, majority of participants support the banning of prostitution, gambling and casino.

This study contributes to the body of knowledge in three areas as follows:

1. The perceptions of non- Muslim tourists towards halal products and services and its impact on trip value and trip quality.

2. Identification of three aspects of travel constraints associated with Halal Tourism

3. Establishing the fact that non-Muslim tourists are willing to try halal tourism experience, or at least purchase certain types of halal products and services.

It is hoped that this paper has succeeded in providing some original insights into the inter-actions between the religion of Islam religion and non-Muslim tourists. The insight should be of value to authorities, the industry, and academics in both Muslim and non-Muslim worlds. Future research should also be conducted in other Islamic countries (e.g. Egypt, Saudi Arabia and Yemen) which have different cultures and history from Malaysia. This will facilitate the understanding of the effect of Halal tourism on the socio cultural impacts of tourism. The findings of this study should help marketers better understand the impact of Halal tourism' and assist in develop new marketing strategies to attract non-Muslim tourists and increase trip quality and value 


\section{References}

1- Akhoondnejad, A. (2015). Analyzing the Pre-Travel, On-Travel, and PostTravel Behaviors of Iran's First-Time Visitors. Journal of Travel \& Tourism Marketing, 32(8), 1023-1033.

2- Al Arabiya News. (2014). No Burkinis! Morocco hotels ban 'halal' suit. Al Arabiya News.

Retrieved from http://english.alarabiya.net/en/variety/2014/08/26/No-Burkinis-Morocco-hotelsban-halal-swimsuit.html

3- Andriotis, K. (2005). Community groups' perceptions of and preferences for tourism development: Evidence from Crete. Journal of Hospitality \& Tourism Research, 29(1), 67-90.

4- Aziz, H. (1995). Understanding attacks on tourists in Egypt. Tourism Management, 16(2), 91-95.

5- Bajs, I. P. (2015). Tourist perceived value, relationship to satisfaction, and behavioral intentions the example of the Croatian tourist destination Dubrovnik. Journal of Travel Research, 54(1), 122-134.

6- Batrawy, A. (2015). 'Halal tourism' on the rise,with apps and curtained pool decks. . $\quad$ Retrieved from http://www.stuff.co.nz/travel/themes/family/73392534/Halal-tourism-on-therise-with-apps-and-curtained-pool-decks

7- Battour, M., Battor, M., \& Bhatti, M. A. (2013). Islamic Attributes of Destination: Construct Development and Measurement Validation, and Their Impact on Tourist Satisfaction. International Journal of tourism research, 16 (6), 556-564.

8- Battour, M., \& Ismail, M. N. (2014). The Role of Destination Attributes in Islamic Tourism. SHS Web of Conferences, 12, 01077.

9- Battour, M., \& Ismail, M. N. (2016). Halal tourism: Concepts, practises, challenges and future. Tourism Management Perspectives.

10- Battour, M., Ismail, M. N., \& Battor, M. (2011). The impact of destination attributes on Muslim tourist's choice. International Journal of tourism research, 13(6), 527-540.

11- Battour, M., Ismail, M. N., Battor, M., \& Awais, M. (2014). Islamic Tourism: An Empirical Examination of Travel Motivation and Satisfaction in Malaysia. Current Issues in Tourism.

12- Battour, M. M., Ismail, M. N., \& Battor, M. (2010). Toward a halal tourism market. Tourism Analysis, 15(4), 461-470. 
13- Bigne, J. E., Sanchez, M. I., \& Sanchez, J. (2001). Tourism image, evaluation variables and after purchase behaviour: inter-relationship. Tourism Management, 22(6), 607-616.

14- Burton, R. (1995). Travel Geography Pitman: London.

15- Carboni, M., \& Janati, M. h. I. (2016). Halal tourism de facto: A case from Fez. Tourism Management Perspectives.

16- Carboni, M., Perelli, C., \& Sistu, G. (2014). Is Islamic tourism a viable option for Tunisian tourism? Insights from Djerba. Tourism Management Perspectives, 11(0), 1-9.

17- Chen, C.-F., \& Tsai, D. (2007). How destination image and evaluative factors affect behavioral intentions? Tourism Management, 28(4), 1115-1122.

18- Chen, H.-J., Chen, P.-J., \& Okumus, F. (2013). The relationship between travel constraints and destination image: A case study of Brunei. Tourism Management, 35(0), 198-208.

19- Cohen-Hattab, K. (2010). Struggles at holy sites and their outcomes: the evolution of the Western Wall Plaza in Jerusalem. Journal of Heritage Tourism, $5(2), 125-139$.

20- Cong, L. C. (2016). A formative model of the relationship between destination quality, tourist satisfaction and intentional loyalty: An empirical test in Vietnam. Journal of Hospitality and Tourism Management, 26, 50-62.

21- Delener, N. (1994). Religious contrasts in consumer decision behaviour patterns: their dimensions and marketing implications. European Journal of Marketing, 28(5), 36-53.

22- Din, K. H. (1989). Islam and tourism: Patterns, issues, and options. Annals of Tourism Research,

23- Dugan, B. (1994). Religion and food service. The Cornell Hotel and Restaurant Administration Quarterly, 35(6), 80-85.

24- Eid, R., \& El-Gohary, H. (2015). The role of Islamic religiosity on the relationship between perceived value and tourist satisfaction. Tourism Management, 46(0), 477-488.

25- El-Gohary, H. (2016). Halal tourism, is it really Halal? Tourism Management Perspectives.

26- Essoo, N., \& Dibb, S. (2004). Religious influences on shopping behaviour: An exploratory study. Journal of Marketing Management, 20(7-8), 683-712.

27- Euromonitor International. (2015). Doing business in the halal market: products, trends, and growth opportunities. Retrieved from http://go.euromonitor.com/white-paper-business-halal-market-productstrends-growth-opportunities.html 
28- Ferns, B. H., \& Walls, A. (2012). Enduring travel involvement, destination brand equity, and travelers' visit intentions: A structural model analysis. Journal of Destination Marketing \& Management, 1(1), 27-35.

29- Fleischer, A. (2000). The tourist behind the pilgrim in the Holy Land. International Journal of Hospitality Management, 19(3), 311-326.

30- Forgas-Coll, S., Palau-Saumell, R., Sánchez-García, J., \& Callarisa-Fiol, L. J. (2012). Urban destination loyalty drivers and cross-national moderator effects: The case of Barcelona. Tourism Management, 33(6), 1309-1320.

31- Fornell, C., \& Larcker, D. F. (1981). Structural equation models with unobservable variables and measurement error: Algebra and statistics. Journal of marketing research, 382-388.

32- Gallarza, M. G., \& Saura, I. G. (2006). Value dimensions, perceived value, satisfaction and loyalty: an investigation of university students' travel behaviour. Tourism Management, 27(3), 437-452.

33- Gössling, S. (2002). Human-environmental relations with tourism. Annals of Tourism Research, 29(2), 539-556.

34- Gursoy, D., S. Chen, J., \& G. Chi, C. (2014). Theoretical examination of destination loyalty formation. International Journal of Contemporary Hospitality Management, 26(5), 809-827.

35- Hashim, N. H., Murphy, J., \& Hashim, N. M. (2007). Islam and online imagery on Malaysian tourist destination websites. Journal of Computer- Mediated Communication, 12(3), 1082-1102.

36- Henderson, J. C. (2003). Managing Tourism and Islam in Peninsular Malaysia. Tourism Management, 24(4), 447-456. doi:http://dx.doi.org/10.1016/S02615177(02)00106-1

37- Henderson, J. C. (2006). Tourism in Dubai: overcoming barriers to destination development. International Journal of tourism research, 8(2), 87-99. doi: $10.1002 /$ jtr.557

38- Henderson, J. C. (2008). Representations of Islam in official tourism promotion. Tourism Culture \& Communication, 8(3), 135-145.

39- Henderson, J. C. (2010). Chapter 6: Islam and tourism. In Bridging Tourism Theory and Practice. Scott, N. and Jafari, J. (eds): Emerald Group Publishing.

40- Henderson, J. C. (2010). Sharia-compliant hotels. Tourism and Hospitality research, 246-254.

41- Henderson, J. C. (2016). Halal food, certification and halal tourism: Insights from Malaysia and Singapore. Tourism Management Perspectives.

42- Higgins-Desbiolles, F. (2006). More than an "industry": The forgotten power of tourism as a social force. Tourism Management, 27(6), 1192-1208. 
43- Jafari, J., \& Scott, N. (2014). Muslim world and its tourisms. Annals of Tourism Research, 44(0),

44- Javed, N. (2007). Islamic Hotel Branding and Muslim Hospitality. Available at http://www.salesvantage.com/article/1143/Islamic-Hotel-Branding-MuslimHospitality (accessed 13 June 2008).

45- Jennings, G., \& Weiler, B. (2006). Mediating meaning: Perspectives on brokering quality tourist experiences. Quality tourism experiences, 57-78.

46- Kim, J.-H., Ritchie, J. B., \& McCormick, B. (2010). Development of a scale to measure memorable tourism experiences. Journal of Travel Research, 0047287510385467.

47- Loganathan, N., \& Ibrahim, Y. (2010). Forecasting international tourism demand in Malaysia using Box Jenkins Sarima application. South Asian Journal of Tourism and Heritage, 3(2), 50-60.

48- Mansperger, M. (1995). Tourism and cultural change in small-scale societies. Human Organization, 54(1), 87-94.

49- Mohsin, A., \& Ryan, C. (1997). Business Visitors to the Northern Territory $\begin{array}{llll}\text { Expo. Tourism } & \text { Recreation }\end{array}$ doi:10.1080/02508281.1997.11014807

50- Nyaupane, G. P., Timothy, D. J., \& Poudel, S. (2015). Understanding tourists in religious destinations: A social distance perspective. Tourism Management, 48(0), 343-353.

51- Ozdemir, I., \& Met, O. (2012). The expectations of Muslim religious customers in the lodging industry: The case of Turkey. Current issues in hospitality and tourism research and innovation, 323-328.

52- Poria, Y., Butler, R., \& Airey, D. (2003). The core of heritage tourism. Annals of Tourism Research, 30(1), 238-254.

53- Raj, R., \& Morpeth, N. D. (2007). Introduction: establishing linkages between religious travel and tourism. Religious tourism and pilgrimage festivals management: an international perspective, 1-14.

54- Robinson, A. J., \& Meaton, J. (2005). Bali beyond the bomb: disparate discourses and implications for sustainability. Sustainable Development, 13(2), 69-78.

55- Ryan, C. (2016). Halal tourism. Tourism Management Perspectives.

56- Snaith, T., \& Haley, A. (1999). Residents' opinions of tourism development in the historic city of York, England. Tourism Management, 20(5), 595-603.

57-Song, Z., Su, X., \& Li, L. (2013). The indirect effects of destination image on destination loyalty intention through tourist satisfaction and perceived value: 
The bootstrap approach. Journal of Travel \& Tourism Marketing, 30(4), 386409.

58- Stephenson, M. L. (2014). Deciphering 'Islamic hospitality': Developments, challenges and opportunities. Tourism Management, 40(0), 155-164.

59- Syed, O. A. (2001). Catering to the needs of Muslim travellers. Paper presented at the 2nd Conference of Ministers from Muslim Countries, Tourism: Challenges and Opportunities, Kuala Lumpur, 10-13 October.

60- Tasci, A. D., Meydan, S. U., \& Cavusgil, S. T. (2006). Destination image: The case of Turkey. Tourism Analysis, 11(2), 79-93.

61- Teye, V., Sirakaya, E., \& Sönmez, S. F. (2002). Residents' attitudes toward tourism development. Annals of Tourism Research, 29(3), 668-688.

62- Thyne, M., Lawson, R., \& Todd, S. (2006). The use of conjoint analysis to assess the impact of the cross-cultural exchange between hosts and guests. Tourism Management, 27(2), 201-213.

63- Timothy, D. J., Timothy, D., \& Olsen, D. (2006). Tourism, religion and spiritual journeys (Vol. 4): Routledge.

64- Vukonic, B. (2002). Religion, tourism and economics: A convenient symbiosis. Tourism Recreation Research, 27(2), 59-64.

65- WTM. (2007). The World Travel Market Global Trend Reports 2007. Retrieved from

66- Žabkar, V., Brenčič, M. M., \& Dmitrović, T. (2010). Modelling perceived quality, visitor satisfaction and behavioural intentions at the destination level. Tourism Management, 31(4), 537-546.

67- Zamani-Farahani, H., \& Henderson, J. C. (2010). Islamic tourism and managing tourism development in Islamic societies: the cases of Iran and Saudi Arabia. The International Journal of Tourism Research, 12(1), 79.

68- Zamani-Farahani, H., \& Musa, G. (2012). The relationship between Islamic religiosity and residents' perceptions of socio-cultural impacts of tourism in Iran: Case studies of Sare'in and Masooleh. Tourism Management, 33(4), 802814.

69- Zulkharnain, A., \& Jamal, S. A. (2012). Muslim guest perception of value towards Syariah concept hotel. Current Issues in Hospitality and Tourism: Research and Innovations, 337. 